\title{
Bint Al-Shati' Critical Thematic Method and the Difference with Others
}

\section{Achmad Khudori Soleh}

Universitas Islam Negeri Maulana Malik Ibrahim Malang, Indonesia

khudorisoleh@pps.uin-malang.ac.id

DOI: $10.29240 /$ alquds.v5i1.2610

Submitted: 2021-03-22 | Revised: 2021-05-01 | Accepted: 2021-06-02

\begin{abstract}
Bint al-Shați' is one of the few modern Muslim female figures who developed Islamic scholarship, especially interpretation of the Al-Qur'an. Issa J Boullata praised the Bint al-Shati' method as a modern interpretation method that has many advantages. The first objective is to identify the background and principles of the Bint al-Shati' method of interpretation. The second objective, to find the peculiarities and advantages of the method compared to others. The third objective is to find important things as a logical consequence of the method of interpretation. This study uses content analysis and comparison method. The author calls the Bint al-Shati' method the term critical thematic method, developed based on the weaknesses of the classical interpretation method. This method has its uniqueness even though it was adopted from the method of interpretation of Amin al-Khuli. The Bint al-Shati' method, compared to several other methods, appears to be more complete and relatively more guarantees that the Qur'an is able to speak for itself. In the end, the principle of no synonym in the Bint al-Shati' method can strengthen the dictum of Abu Abbas Tsa'lab, can provide certainty about the stages of a legal process, and can strengthen certain theological understandings.
\end{abstract}

Keywords: Bint al-Shatii', interpreter qualifications, classical interpretation, modern interpretation, critical thematic method, literary analysis

\section{Introduction}

There are not many commentators in the twentieth century who offer new methods of interpreting the Al-Qur'an. Most of them still use the classical method in their works, such as the method of tablili, ijmali, muqaran and others. The tablili method is interpreting the Al-Qur'an in tartil according to the order of verses and letters; The ijmali method is interpreting the al-Qur'an globally usually only explaining the essential points of a letter; The muqaran method is interpreting the Al-Qur'an with how to compare one verse with another verse or one opinion with another opinion related to interpretation. 
Bint al-Shati' (1913-1998) is one of the few modern Muslim women who studied and developed Islamic scholarship, especially in exegesis. His work, which was published in 1962, namely al-Tafsîr al-Bayânî li Al-Qur'an al-Karîm, received an extraordinary reception from academics. Therefore, Bint al-Shați' received invitations to give lectures and conferences in various countries, such as Italy, Algeria, India, Iraq, Kuwait, Jerusalem, Morocco, and Sudan. ${ }^{1}$ In this work, Bint al-Shați' uses a new method that was not previously known.

Issa J Boullata (1929-2019) praised Bint al-Shați' as a modern interpreter whose method has many added values, both from a theological point of view, literary criticism and others. ${ }^{2}$ From the aspect of the feminist movement, Ruth Roded considers that Bint al-Shati' is a pioneer of feminist thinking of Muslim women in the modern era. ${ }^{3}$

The author himself sees that the Bint al-Shati' method of interpretation contains the basics unique to the thematic interpretation method. Exploration and study of the method of interpretation as a whole will enrich and complement the existing method of interpretation and be able to make our understanding of the Al-Qur'an better. Therefore, this paper will first describe Bint al-Shatị' criticism of the weaknesses of classical interpretation. This criticism is essential as a basis for understanding why Bint al-Shatịi came up with his method. After that, it identifies its interpretation method, understands its rejection of Israiliyyat sources, and its efforts to keep the Al-Qur'an interpretation so that it is not infiltrated by outside thinking. It also compares with the methods of interpretation of other figures so that their originality becomes clear.

\section{Articles Review and Analysis Method.}

Many journal articles are discussing Bint al-Shati' thoughts, both international journals and national journals. In international journals, the author found at least five articles. First, the writings of Issa J Boullata (1929-2019). Boullata was the first to discuss the Bint al-Shați method of interpretation. According to him, the Bint al-Shați' interpretation method consists of four stages. Namely, collecting verses in the same theme, arranging the verses according to the chronology of their descent, analyzing the verses using Arabic rules, holding on to the text's spirit. ${ }^{4}$ Second, Shuruq Naquib's article writes about the basic principles of Bint al-Shați' interpretation. According to him, Bint al-Shați' used

${ }^{1}$ Muhammad Amin, “A Study of Bint Al-Shati Exegesis” (McGill University, 1992). 13.

${ }^{2}$ Issa J. Boullata, "Modern Qur'anic Exegesis: A Study of Bint Al-Shati’s Method," The Muslim World LXIV, no. 4 (1974): 103-13, https://doi.org/10.1111/j.1478-1913.1974.tb03145.x.

${ }^{3}$ Ruth Roded, "Bint Al-Shati's Wives of the Prophet: Feminist or Feminine," British Journal of Middle Eastern 33, no. 1 (2006): 51-66, https:/ / doi.org/10.1080/13530190600603915.

${ }^{4}$ Boullata, "Modern Qur'anic Exegesis: A Study of Bint Al-Shati's Method." 
the interpretive principles of Amin al-Khuli (1895-1966), but she modified it to be different from al-Khuli. ${ }^{5}$

Third, Ruth Roded's writing which discusses the feminist thought of Bint al-Shati' is based on his work entitled Wives of the Prophet. According to her, Bint al-Shatii' is the first modern Muslim woman to discuss the theme of feminism by making women around the Prophet as her study material. ${ }^{6}$ Fourth, the article by Jarot Wahyudi wrote about the Bint al-Shati' interpretation method. According to him, Bint al-Shați' has been instrumental in finding a method of understanding the Al-Qur'an. The use of language literally and metaphorically to understand the verse's meaning is an original contribution from Bint al-Shați'.

Fifth, Shalahudin Kafrawi's article was comparing Bint al-Shati's exegesis method with Sayyid Qutub. According to him, Bint al-Shați' has something in common with Sayyid Qutub in that both of them make al-Qur'an a guide for life. However, the two differ in their methods of understanding their meaning. ${ }^{8}$

In Indonesia, there are relatively many articles about Bint al-Shați' in national journals. First, Mardan's article analyzes the Bint al-Shati' interpretation method. This article is the first paper on the Bint al-Shati' method of interpretation. According to him, Bint al-Shați' uses the maudhui, tablili, and muqaran methods, while the interpretations are ilmy and ijtimai. ${ }^{9}$ Second, Wahyuddin's article on Bint al-Shați' style and interpretation method..$^{10}$ However, this article published in 2014 is no different from the previous writings of Issa J Boullata (1929-2019).

${ }^{5}$ Shuruq Naguib, "Bint Al-Shati”s Approach to Tafsir: An Egyptian Exegete's Journey from Hermeneutics to Humanity (Review)," Journal of Qur'anic Studies 17, no. 1 (2015): 45-84, https://doi.org/10.3366/jqs.2015.0179.

${ }^{6}$ Roded, "Bint Al-Shati's Wives of the Prophet: Feminist or Feminine."

7 Jarot Wahyudi MD, "LITERARY INTERPRETATION OF THE QUR'ĀN: 'FAWĀṢIL AL-ĀYĀT,' 'QASAM' AND "ISTIFHĀM, ' THREE EXAMPLES FROM BINT AL-SHĀṬ̂'S ‘TAFSĪR,”’ Islamic Studies 37, no. 1 (1998): 19-28.

8 Shalahudin Kafrawi, "METHODS OF INTERPRETING THE QUR'ĀN: A COMPARISON OF SAYYID QUTTB AND BINT AL-SHĀṬI," Islamic Studies 37, no. 1 (1998): $3-17$.

9 Mardan, "TAFSIR KARYA AISYAH ABD AL-RAHMAN BINT AL-SYATHI (Suatu Rekonstruksi Metodologi Tafsir Kontemporer)," Jurnal Adabiyah XI, no. 2 (2011): 166-81.

${ }^{10}$ Wahyuddin, “CORAK DAN METODE TAFSIR BINT AL-SHATI' Studi Atas AlTafsir Al-Bayaniy Li Al-Qur’an Al-Karim,” Epistemé 9, no. 1 (2014): 117-38. 
Third, the articles of Miftahul Jannah ${ }^{11}$ and Alwi and Iin Parninsih, ${ }^{12}$ whom both studied the thoughts of Bint al-Shati' in their book entitled Maqal fi al-Insan Dirasah Qur'aniyah. According to them, Bint al-Shați' is less consistent in using the method it offers. Fourth, the articles of Wali Ramadhani and Wardah, whom both wrote the Bint al-Shați' interpretation method in a book entitled atTafsir al-Bayan li al-Qur'an. According to them, the Bint al-Shatii' method of interpretation is a development of the method of interpretation of Amin al-Khuli $(1895-1966) .^{13}$

Fifth, Maizul Imran and Ismail's articles write about the principle of taraduf (synonymity) in the Bint al-Shați' method of interpretation. According to him, the method of interpretation of Bint al-Shați' emphasizes more on literary studies. As a result, the concept of taraduf that he conveyed was not applicable when it was related to legal issues. ${ }^{14}$

The description above shows that the method of interpreting the $\mathrm{Al}$ Qur'an Bint al-Shați' has not been thoroughly studied. This paper fills this significant gap.

This paper uses content analysis and comparison methods. The author uses content analysis to analyze the workings of Bint al-Shati's interpretation to find the formulation of the new method. Furthermore, the author compares the formulation of Bint al-Shati's interpretation method with the interpretation method of other contemporary figures to show his position and differences with others. Based on these methods and analyzes, the authors hope that readers can clearly understand the uniqueness of the Bint al-Shati exegesis method.

\section{Criticism of Classical Interpretation.}

According to Bint al-Shatii', there are some fundamental weaknesses in the classical interpretation method. First, most classical interpretations interpret the Al-Qur'an in tartil from verse to the next verse in sequence. This method means treating the verses partially and individually apart from other verses as a unified

${ }^{11}$ Miftahul Jannah, "MANUSIA DALAM AL-QUR’AN (Studi Atas Kitab Maqâl Fî AlInsân: Dirâsah Qur'aniyyah Karya 'Â’Isyah ‘Abd Al-Rahman Bint Al-Syathi'),” Ilmu Ushuluddin 16, no. 2 (2017): 81-94.

12 Muhammad Alwi; Iin Parninsih, "MENYOAL KONSISTENSI METODE PENAFSIRAN BINT SYATHI TENTANG MANUSIA (Studi Kitab Maqal Fi Al-Insān: Dirasah Qur'aniyyah)," Al-Bayan: Studi Al-Qur"an DanTafsir 4, no. 2 (2019): 82-92.

13 Wali Ramadhani, "BINTU SYATI' DAN PENAFSIRANNYA TERHADAP SURAH AL-'ASR DALAM KITAB AT-TAFSIR AL-BAYANI LIL QUR'ANIL KARIM," Jurnal At-Tibyan 3, no. 2 (2018): 265-81, https://doi.org/10.32505/tibyan.v3i2.717.

14 Maizul Imran \& Ismail, “Ā'ISHA BINT AL-SHĀṬI'S THOUGHTS ON TARĀDUF AND THEIR IMPLICATIONS FOR THE ISTINBĀṬ OF LAW,” Al-Risalah 19, no. 2 (2019): 125-40, https://doi.org/10.30631/al-risalah.v19i2.459. 
whole so that it becomes separated from the general context of the Al-Qur'an, and we become unable to know the instructions of the Al-Qur'an about laxation, the chronology of the phenomenon of uslub its and characteristics of its-bayan. ${ }^{15}$ Also, this method means that it is not following the principle that the Al-Qur'an is a unified whole where the verses and letters from one another are interrelated and explain one another.

Bint al-Shati' criticism is indeed correct. In fact, from al-Tabari (838-923) to the modern era, most commentaries use the tartilmethod to interpret the verses of the Al-Qur'an sequentially from one to the next verse.

Second, there are references from outside that are not following the AlQur'an teachings, especially israiliyat. ${ }^{16}$ Israiliyat comes from the Bible (Torah and Gospel), especially about the prophets, the ancient Israelites (Children of Israel), and Jewish folklore. According to Sahiron Syamsuddin, the early period of Muslim scholars got this Islamic information from $\mathrm{Abl}$ al-Kitab, who converted to Islam, such as Ka'b al-Ahbar (d. 652) and Wahab ibn Munabbih (655-737). Some friends such as Salman al-Farisi (567-653), Zayd ibn Thabit (610-660) (chief editor of the Al-Qur'an at the time of the Caliph Usman ibn Affan (644-656), and Abdullah Ibn Abbas (619-687) friends known as Father of Qur'anic interpretation is reported to have sufficient knowledge about Israelis and has passed this knowledge on to others. ${ }^{17}$

In the next phase, Ibn Jarir al-Tabari (839-923) used israiliyat information to interpret the al-Qur'an verses that talk about Bible prophets and their communities. Some later figures such as Ibn al-Khalil al-Khazin (1299-1362) and Abd al-Rahman al-Tha'alibi (1384--1479) followed the al-Tabari approach. Interpreters continue to take information from Israel for two reasons: (1) The Prophet himself did not explicitly forbid taking information from Israel, (2) the al-Qur'an also talks about the Children of Israel so that there is no way to search for more detailed information except referring to israiliyat stories. ${ }^{18}$

Bint al-Shati'i rejects the interpretation of the al-Qur'an based on israiliyat information as in classical interpretations for two reasons. First, israiliyat information itself is very diverse, different, even contradictory, so it is not worthy of reference. Second, according to literary

${ }^{15}$ Aishah Abd Rahman Bint al-Shati', Al-Tafsir Al-Bayani Li Al-Qu'an Al-Karim, I (Cairo: Dar al-Ma'arif, 1990). 17.

${ }^{16}$ Bint al-Shati'. 16.

${ }^{17}$ Sahiron Syamsuddin, "An Examination of Bint Al-Shati"s Method of Interpreting the Qur'an” (McGill University, 1998). 10.

18 Syamsuddin. 12. 
analysis, the interpretation of the text must be based on the text itself so that it uses references outside of the al-Qur'an which in this case is Islamic information becomes irrelevant. Based on this, Bint al-Shati' then called on the commentators to use the verses of the Al-Qur'an themselves to interpret the Al-Qur'an. ${ }^{19}$

Third, there are self-commenting ideas which are not following the intended interpretation of the verse. ${ }^{20}$ These ideas are usually related to the interpreters' thoughts, be it theology, jurisprudence, mysticism, language, or something else. ${ }^{21}$

Bint al-Shati's criticism of this classical interpretation method is not unwarranted. In fact, after al-Tabari's interpretation, the commentary books always have a particular style that seems clear that the author 'imposed something on the Al-Qur'an', which can be in the form of theology, jurisprudence, mysticism, or at least the flow of specific language rules. This statement can be proven, for example, in the interpretation of al-Kashshaf by Ibn Umar alZamakhshari (1074-1143), Anwar al-Tanzil by Ibn Umar al-Baidawi (d. 1286), or Babr al-Mubit by Abu Hayyan al-Gharnati (1256-1344). ${ }^{22}$

\section{Principles and Methods.}

Based on the classical interpretation method's weaknesses above, Bint alShați' proposed his new interpretation method. This method is based on three main principles. First, the principle that Al-Qur'an explains itself (al-Qur'an yufassiru ba'dubu ba'dan). According to Kamal al-Haydari (b. 1956), this is the main principle in interpreting the Koran. This principle is based on the Prophet's hadith and the statement of Ali ibn Abi Talib (601-661). Allah's Messenger stated that some verses of the Al-Qur'an confirm other verses (Inna al-Qur'an liyusaddiga ba 'dubu ba dan). Meanwhile, Ali ibn Abi Talib (601-661) stated that the al-Qur'an verses discuss and witness with one another. ${ }^{23}$

According to al-Haydari, commentators from Sunni and Shia circles, such as Ibn Jarir al-Tabari (839-923) and Fakhr al-Din al-Razi (1150-1210), also Abu Jakfar al-Tusi (995-1067), Ibn Hasan al-Tabrizi (1073-1153), and Muhammad alTabatabai (1842-1920) recognized and followed this principle. ${ }^{24}$ Ibn Umar alZamakhshari (1075-1144), a Muktazilah figure, stated, "think of this. Indeed, part of

\footnotetext{
${ }^{19}$ Syamsuddin. 16-17.

${ }^{20}$ Bint al-Shati', Al-Tafsir Al-Bayani Li Al-Qu'an Al-Karim. I: 18.

${ }^{21}$ Syamsuddin, "An Examination of Bint Al-Shati"s Method of Interpreting the Qur'an."

10.

${ }^{22}$ Mahmud Shaltut, Tafsir Al-Qur'an Al-Karim (Cairo: Dar al-Qalam, n.d.). 7.

${ }^{23}$ Kamal Al-Haydari, Usul Al-Tafsir Wa Al-Ta'wil, ed. Abd al-Rida Al-Iftikhary (Teheran: Satarah, 2012). 59.

${ }^{24}$ Al-Haydari.
} 
the Al-Qur'an interprets another". ${ }^{25}$ In the modern era, we came to know Fazlur Rahman (1919-1988) to bring up the famous jargon, "let the Koran speak for itself". ${ }^{26}$

Second, the principle that the Al-Qur'an is a unified whole with unique expressions and language styles. ${ }^{27}$ Related to this, Ibn Musa al-Sațibi (1320-1388) once stated that kalamu-llabi buwa kalamun wabidun (God's Speech is a unitary Speech). Furthermore, al-Shatibi states, "The meaning of one part of the Al-Qur'an is somebow dependent on another part. That is because the meanings of many verses Al-Qur'an are not understood correctly without referring to other verses" ${ }^{28}$ Therefore, each verse of the Al-Qur'an must be associated with other verses by paying attention to the language's details, not understood and interpreted independently of other verses.

Third, the principle that the study of the Al-Qur'an content must be related to the context of the descending verses (asbab al-nuzul) not only based on the meaning of the word. ${ }^{29}$ However, Bint al-Shați' does not value asbab al-nu₹ul as the cause of the revelation, especially as the purpose of revelation, such as the understanding of many interpreters, but only information about the external conditions of revelation. That is, Bint al-Shați' pays more attention to the universal meaning of the verse indicated in the existing conditions rather than the specific context that accompanies the passage of the verse. ${ }^{30}$ This third principle follows the usul al-figh rules, which states "al-ibrah bi umum al-lafz̧i la bi khușus alsabab" (a reference is the universal meaning of the verse, not the specific cause of the verse).

Besides being based on the three principles above, Bint al-Shatii' also bases itself on the interpretation method of Amin al-Khuli (1895-1966), her husband, and teacher. The al-Khuli method itself consists of two steps; (1) identify verses that are similar and then arrange them according to the chronology of the descending verses, (2) study the asbâb al-nuzûul of the verses studied or interpreted. ${ }^{31}$

${ }^{25}$ Ibn Umar Al-Zamakhshari, Al-Kashshaf 'an Haqaiq Al-Tanzil Wa 'Uyun Al-Aqawil Fi Wujuh Al-Ta'wil (Beirut: Dar al-Kutub, n.d.). II: 430.

${ }^{26}$ Fazlur Rahman, Major Themes of the Qur'an (Chicago: Bibliotheca Islamica, 1980). V.

${ }^{27}$ Bint al-Shati', Al-Tafsir Al-Bayani Li Al-Qu'an Al-Karim. I: 17.

${ }^{28}$ Ibn Musa Al-Satiibi, Al-Muwafaqat, ed. Abd Al-Hamid (Cairo: Maktabah M Ali Sabih, 1969). III: 284.

${ }^{29}$ Aishah Abd Rahman Bint al-Shati', Al-Tafsir Al-Bayani Lil Al-Qur'an Al-Karim, II (Cairo: Dar al-Ma'arif, 1968). 8.

${ }^{30}$ Bint al-Shati'. II: 9.

${ }^{31}$ Amin, "A Study of Bint Al-Shati Exegesis." 32. 
Based on the three main principles and the two methods of interpretation of Amin al-Khuli (1895-1966) above, Bint al-Shați' then formulated his interpretation method consisting of 4 steps; ${ }^{32}$

1. Gather all verses related to the topic of study. Collecting one theme from the whole verse does not mean denying the fact that the Koran descended over a long period in which the style of expression may differ between the first and the next because this is the single most good way to understand the meaning of the Al-Qur'an.

2. Arrange verses with the same theme in descending order so that the chronology of the revelation and its external conditions (asbâb al-nu₹ûu) can be known. However, Bint al-Shati does not see asbâb al-nužul as the cause of the decline of the verse but only a description of the revelation conditions of a particular verse. As the description of the third principle above, the concern is the universality of the meaning of the verse and not the specifics of the revelation event (al- 'ibrah bi'umûm al-lafzi la bikhusûs al-sabâb). Therefore, there is no reason to say that this method will be confused by the scholar's debate about asbâb al-nu₹ûl. ${ }^{33}$

3. To understand the directions of death, because the Al-Qur'an uses Arabic, it must seek guidance in the original language which gives a sense of language for different lives, then conclude the instructions by examining all forms of death in it, and by looking for specific and general contexts in the verses of the Koran as a whole. Here we use language analysis (semantics).

4. To understand confusing statements, an interpreter must hold on to the meaning of the verse and its enthusiasm (maqâshid al-syar'i), then confront the opinions of other interpreters. However, an interpreter will only accept opinions that are in line with the intent of the verse and reject opinions that are sectarian and israiliyat.

With this method, Bint al-Shati' means to have made strict rules to ensure that the Al-Qur'an speaks about itself without the intervention of interpreters, and he hopes we can now understand the verses of the al-Qur'an and as the companions of the Prophet understood it. Associated with asbab al-nuгul, Bint alShatii understands it only as historical data, not as a reason for the passage of the verse, let alone the purpose of the verse, so that the content of the word of God will be eternal, not confined by a specific time and space.

Based on this, Bint al-Shați' often criticized classical commentators such as Ibn Jarir al-Tabari (839-923), Ibn Umar al-Zamakhshari (1075-1144), Fakhr al-

${ }^{32}$ Bint al-Shati', Al-Tafsir Al-Bayani Li Al-Qu'an Al-Karim. I: 10-11.

${ }^{33}$ Syamsuddin, "An Examination of Bint Al-Shati"s Method of Interpreting the Qur'an.”

83. 
Din al-Razi (1150-1210), Raghib al-Isfahani (d. 1108). Bint al-Shati' also criticized Nizam al-Din al-Naisaburi (d. 1328), Abu Hayyan al-Andalusi (1256-1344), Ibn Qayyim al-Jauzi (1292-1350), and Jalal al-Din al-Suyuthi (1445-1505) if she judged that their opinions were not following the method she had developed.

One example, in this case, is asbâb al-nu₹ûl surah al-Duhâ. According to Ibn Jarir al-Tabari (839-923), Fakhr al-Din al-Razi (1150-1210), and Jalal al-Din al-Suyuthi (1445-1505), this letter came down in response to the Quraysh statement that his Lord has abandoned the Messenger of Allah. However, this letter itself was very late coming down, up to 2 months. According to Fakhr alDin al-Razi (1150-1210), the cause of the delay was that the Prophet promised an answer without saying the word Insha Allah to the Jewish question about the soul, Dhu al-Qarnain and Ashâb al-Kahf. Another reason is that this letter was late because of the puppies belonging to the Apostles' grandchildren, namely Hasan (624-669) and Huseyn (626-680) in his house, so Gabriel said, "Don't you know that we did not enter the house with dogs or the picture", or because there was a family of Apostles who did not cut his nails. ${ }^{34}$

According to Bint al-Shati', the reason for the delay of the revelations conveyed by Fakhr al-Din al-Razi (1150-1210) above was too pushy. The reason explicitly stated by this verse is that the delay of revelation is a natural phenomenon such as the silence of the night after Duha, nothing more than that. If the Al-Qur'an considers it necessary to explain the delay, that is to calm the soul; of course, he will not remain silent because the purpose of the bayan AlQur'an is to fulfil all the demands of the situation goal. If the Al-Qur'an does not discuss things like that, it means that the importance is the universality of meaning, not the existing context's specifications. ${ }^{35}$

\section{Protection from External Influence.}

To ensure that the Al-Qur'an speaks about itself, not affected from outside, Bint al-Shatii' does the following two things. First, refusing to be involved in detailed discussions about israiliyat, because the Al-Qur'an itself does not provide a detailed description of israiliyat. If the Al-Qur'an touches on israiliyat, it is more a moral example and a spiritual lesson that must be learned, not as historical detail..$^{36}$

Israiliyat originates from the Bible (Torah and Gospel), specifically relating to the Prophets and ancient Israel people (Children of Israel). Friends such as

\footnotetext{
${ }^{34}$ Fakhr al-Din Al-Razi, Al-Tafsîr Al-Kabîr (Beirut: Dar al-Hilal, 1976).

${ }^{35}$ Bint al-Shati', Al-Tafsir Al-Bayani Li Al-Qu'an Al-Karim. I: 35.

${ }^{36}$ Bint al-Shati'. I: 16.
} 
Zayd ibn Thabit (610-660) and Abdullah ibn Abbas (619-687) and others received an Islamic history from the Ahl al-Kitab who had converted to Islam such as Ka'b al-Ahbar (died 652) and Wahab ibn Munabbih (655-737). ${ }^{37}$

Second, refusing to associate the Koran with modern science because the Al-Qur'an itself does not seem to mean that. The Al-Qur'an verses have their intrinsic meaning and can only be understood by studying in their context. If there are newspaper verses that explain natural phenomena, plants, animals, space, and others that are amazing, that does not mean the Al-Qur'an teaches various scientific theories. According to Bint al-Shati', Al-Qur'an is more moral teaching that is eternal, not as a modern scientific theory even though one day it might be in line with it. ${ }^{38}$

Bint al-Shati's attitude, which refused to link the Koran verses with the modern science above, finally involved him in an open debate with Mustafa Mahmud. Mustafa Mahmud is a physicist who tries to bring together modern science theories with the contents in the Al-Qur'an verses. These two figures' debates were published in the newspaper Shabah al-Khair and al-Ahram, Cairo, in March and April 1970. Mustafa Mahmud's articles in this issue were published under the title Al-Qur'an: Mubâwalab li Fabm Ashriy li al-Qur'an (Cairo, Ruz alYusif, 1970). In this book, Mustafa Mahmud explains the history of creation, heaven and hell, doomsday, retribution, halal and haram, and others from the perspective of modern science, so that the Al-Qur'an seems to be very scientific, or at least in line with the concepts of modern science. Meanwhile, Bint al-Shatii's response to Mustafa Mahmud was published under al-Qur'an wa Tafsir alAsriy (Cairo, Dar al-Ma'arif, 1970). ${ }^{39}$

Some commentators such as Mehdi Golshani (b. 1939), Quraish Shihab (b. 1944), and Ahmad Von Denffer (b. 1949) also agreed with Bint al-Shatị' who refused to link the verses of the Koran with specific modern science. ${ }^{40}$ The reason, the truth of the teachings of the Al-Qur'an is eternal, while the truth of science is only temporal and debatable, relative, and will soon replace after new theories or facts emerge. Linking verses of the Al-Qur'an with science is the same as placing the Qur'anic truth in relative conditions and not eternal. According to the Quraysh Shihab (b. 1944), the Al-Qur'an is more moral teaching and drive to

10.

${ }^{37}$ Syamsuddin, "An Examination of Bint Al-Shati"s Method of Interpreting the Qur'an.” Ma'arif, 1970).

38 Aishah Abd Rahman Bint al-Shati', Al-Qur'an Wa Al-Tafsir Al-Asry (Cairo: Dar al-

${ }^{39}$ Boullata, "Modern Qur'anic Exegesis: A Study of Bint Al-Shati's Method."

40 Ahmad Von Denffer, Ulul Al-Qur'an: An Introduction to the Scoence of the Qur'an (London: The islamic Foundation, 2009). 155. 
conduct research and produce discoveries in science, but the Al-Qur'an is not a teaching about science. ${ }^{41}$

\section{Qualification of interpreters.}

According to Bint al-Shati', everyone has the right to understand and interpret the Al-Qur'an according to his abilities. However, to convey the results of their interpretations to the public or publish their interpretative works, it is only the right of people who have the qualifications as interpreters. Not just anyone can do it. ${ }^{42}$

Bint al-Shati' provides specific conditions for a person to qualify as an expert on the Al-Qur'an interpretation. First, interpreters must have extensive knowledge in Arabic, such as grammar (nahwu and șaraf), rhetoric, and language style (balaghah). Secondly, a commentator must understand the Qur'anic vocabulary (mufradat), uslub (style of language), the variety of recitation of the Al-Qur'an known by the seven kinds of readings (qira'ab sab'ab) and others. Third, an interpreter must understand things related to the sciences of the Al-Qur'an (ulum al-qur'an) such as the causes of revelation (asbab al-nuzul), concerning clear verses (mubkamat), vague verses (mutashabihat) and others. Fourth, an interpreter must have extensive knowledge in the science of hadith, theology, Islamic jurisprudence (fiqh), Islamic history, and matters about heresy (heresiology). ${ }^{43}$

Because of this, Bint al-Shati' strongly rejects the opinion of people who state that some of the figures like Abdullah Ibn Abbas (619-687) were not people who specialized in interpretation even though they judged to have authority in the field of interpretation. According to this opinion, people who do not have interpreters' qualifications may also interpret the Al-Qur'an. According to Bint alShati', that is a very baseless opinion. Ibn Abbas and other Companions were figures who had a solid and broad Arabic knowledge base. Moreover, most importantly, they are educated directly by the Messenger of Allah, and there is no better educational outcome than the Prophet's training results. ${ }^{44}$

Therefore, in the name of modernity and a society that highly respects scientific specialization, Bint al-Shati' strongly rejects the validity of the Al-Qur'an

\footnotetext{
${ }^{41}$ Quraish Shihab, Membumikan Al-Qur'an (Bandung: Mizan, 1997). 41.

${ }^{42}$ Bint al-Shati', Al-Qur'an Wa Al-Tafsir Al-Asry. 46.

${ }^{43}$ Bint al-Shati'. 32.

${ }^{44}$ Bint al-Shati'. 35.
} 
interpretation delivered and published by people who do not have qualifications in this field. ${ }^{45}$

\section{Difference with other.}

To better understand the Bint al-Shati' method, the author will compare it with the other methods, namely the method of Toshihiko Izutzu (1914-1993), Muhammad al-Ghazali (1917-1996), Fazlur Rahman (1919-1988), M Shahrur (1938 -2019) and Abd al-Hay al-Farmawi (1942-2017). All of these figures lived contemporaneous or after Bint al-Shați' and together sought to study the AlQur'an in specific themes (thematic).

In 1966 Toshihiko Izutsu (1914-1993) studied the Al-Qur'an ethics with a language approach, understanding the Al-Qur'an through its parent language, namely Arabic, according to its locus. Izutzu tried to understand specific themes in the Al-Qur'an, namely ethical issues, by examining related passages by analyzing the sociology of language, namely how and in what sense the language or words first used. ${ }^{46}$ This Izutsu method from the aspect of language analysis resembles the third step of Bint al-Shați', but Bint al-Shați' emphasizes the Al-Qur'an source itself, not from outside sources such as Izutsu.

Abd al-Hayy al-Farmawi (1942-2017), professor at the Faculty of Usuluddin al-Azhar, Cairo, in 1977, wrote a book on the thematic method with steps similar to those of Bint al-Shatị'. That is (1) collecting similar verses, (2) compiling the verse according to the chronology of the asbab al-nuгûl, (3) completing the discussion with relevant hadiths, (4) compromising am and distinctive, mutlaq and muqayyad, to produce understanding as a whole. ${ }^{47}$ The alFarmawi method is relatively reasonable and complete, but there is no solution when there is language difficulty, also when there is no information whatsoever to understand the meaning of the verse studied. Quraish Shihab also gave notes for the development of this method of al-Farmawi interpretation. ${ }^{48}$

Fazlur Rahman (1919-1988), in 1980, studied specific themes in the AlQur'an by gathering all related verses then concluding them. However, Rahman did not explain in detail the methods used, nor did he explain how to solve severe problems, so it was not easy to verify the results of his interpretation. ${ }^{49}$

M Shahrur (1938-2019), in 1990, studied specific themes with methods similar to Izutzu, namely semantics. The principles of the method: (1) follow the

\footnotetext{
${ }^{45}$ Bint al-Shati'. 82.

${ }^{46}$ Toshihiko Izutsu, Etika Bergama Dalam Al-Qur'an (Jakarta: Firdaus, 1993).

47 Abd al-Hayy Al-Farmawi, Al-Bidayah Fi Tafsir Al-Maudui (Cairo: al-Arabiyah, 1977).

48 Shihab, Membumikan Al-Qur'an. 115.

${ }^{49}$ Rahman, Major Themes of the Qur'an.
} 
language approach outlined by Abu Ali al-Farisi (919-987 AD), Abu al-Fath Usman ibn al-Jinni (941-1002 AD), and Abd al-Qahir al-Jurjani (1006 -1078 AD). (2) that each verse of the Al-Qur'an has a specific meaning so that there is no synonymity. (3) that what is in the Al-Qur'an is for humans' good and guidance, and human reason can understand it so that there is no conflict between reason and revelation. ${ }^{50}$ Shahrur's statement that each verse of the Al-Qur'an has a specific meaning, not anonymous, is precisely one of the dictums and findings from applying the Bint al-Shati method. Abdul Mustaqim has written an article on Hudud Shahrur's theory in the journal al-Quds. ${ }^{51}$

Muhammad al-Ghazali, in 1996 published a book with the title Nahw Tafsîr Maudûi ili Sunvar al-Qur'an al-Karim. Al-Ghazali, in this work, seeks to express one central theme in every letter of the Al-Qur'an. ${ }^{52}$ However, al-Ghazali did not explain the method for determining the essential themes of each letter referred to, so it was not easy to verify the findings.

Based on the above comparisons, the authors conclude two things. First, chronologically, the Bint al-Shati' method came before the other five figures. Unfortunately, the Bint al-Shati' method is less well known or less recognized. Quraish Shihab, for example, puts al-Farmawi as one of the characters in the thematic method, not Bint al-Shati' even though al-Farmawi's method is actually no different from the Bint al-Shati' method. ${ }^{53}$

Second, methodologically, the Bint al-Shati' method appears to be complete and relatively more guarantees that the Al-Qur'an can speak about itself because the verses in the same theme are arranged by the chronology of their descent and analysed in terms of their language (semantics) before drawing their conclusions. Meanwhile, in Fazlur Rahman and al-Ghazali's methods, there are no rules that guarantee that the conclusion is the meaning or word of the al-Qur'an itself. On the other hand, the Izutsu and Shahrur methods emphasize semantic analysis. Somewhat exaggeratedly, it can be said that the Izutsu and Shahrur methods are a footnote for Bint al-Shati'. The author made this conclusion several years ago. ${ }^{54}$

\footnotetext{
${ }^{50}$ Muhammad Shahrur, Al-Kitab Wa Al-Qur'an Qira'ab Mu asirah (Damaskus: al-Ahali, 1992).

51 Abdul Mustaqim, "Teori Hudûd Muhammad Syahrur Dan Kontribusinya Dalam Penafsiran Alquran," Al-Quds Jurnal Studi Alquran Dan Hadis 1, no. 1 (2017): 1-26, https://doi.org/10.29240/alquds.v1i1.163.

${ }^{52}$ Muhammad Al-Ghazali, Nahw Tafsîr Maudûi Li Suwar Al-Qur'an Al-Karîm (Cairo: Dar al-Ma'arif, 1996).

${ }^{53}$ Shihab, Membumikan Al-Qur'an. 114.

${ }^{54}$ Achmad Khudori Soleh, Pemikiran Islam Kontemporer, ed. Achmad Khudori Soleh (Yogyakarta: Jendela, 2003). 121.
} 


\section{Findings and Criticism.}

In this section, the authors convey several things. First, the Bint al-Shati' method shows that linguists' philosophy usually considers synonymous does not exist. Every word used in the Al-Qur'an has its specific meaning and cannot be replaced by other words which are considered synonymous. For example, the words halafa and aqsama (to swear), that the word halafa is used for false oaths while aqsama is for valid paths that have never been intended to violate. ${ }^{55}$

This finding strengthens the dictum of Abu Abbas Tsa'lab (809-900), which states, "whatever is considered synonymous in linguistic studies actually has a different meaning" (ma yuzhannu fi al-dirasah al-lughawiyah min al-mutaradifat buwa min al- mutabayinat). ${ }^{56}$ This dictum encouraged Ibn Faris al-Qazwini (9411004) to create a famous dictionary, namely Mu'jam Maqayis al-Lughah. This dictionary recognizes no synonymity. This dictionary can explain the different meanings of each of the words discussed and even distinguishes between nouns as subject (zat) and nouns as properties (sifat).

Second, the Bint al-Shati 'method, which requires a commentator to compile a verse that is thematic by the chronology of the revelation, shows that the method of exegesis of the al-Qur'an Bint al-Shati is thematic. Chronologically, the formulation of Bint al-Shati's thematic method was earlier than Abd al-Hayy al-Farmawi (1942-2017), who also delivered the same method. However, Bint alShati remains different from al-Farmawi because he combines it with literary criticism. The author calls this combined method of interpretation of Bint al-Shati the term "critical thematic method". This term is also to distinguish it from the new thematic method from Sayyid Ahmad al-Kumi, which the author calls the thematic orientation method (ghardli). ${ }^{57}$

Third, Bint al-Shati's thematic method, which requires a commentator to compose a theme according to the chronology of revelation, can provide convincing information about the stages of the process of determining the law and its purpose (maqâsid al-tashri ). These findings, among others, are seen in the process and chronology of the prohibition of intoxicating beverages.

Fourth, theologically, this method can show that the will that brings consequences is the will that has been in the form of action, not just an intellectual abstraction. Apart from that, the will in the form of that action is also not a compulsion. This finding is based on a study of the word arada (will). This word

\footnotetext{
${ }^{55}$ Bint al-Shati', Al-Tafsir Al-Bayani Li Al-Qu'an Al-Karim. I: 172.

${ }^{56} \mathrm{Ja}$ far Dikk Al-Bab, "Al-Manhaj Al-Lughawi Fi Al-Kitab," in Al-Kitab Wa Al-Qur'an Qira'ah Mu asirah, ed. M Shahrur (Damaskus: al-Ahali, 1992). 24.

${ }^{57}$ Ahmad al-Sayyid and Muhammad Yusuf Qasim Kumi, Al-Tafsir Al-Mandu i Li AlQur'an Al-Karim, 1st ed. (Cairo, 1982).
} 
never appears in a noun but always in the verb, mâdî or (mudâri ). The word arada also does not appear in the imperative and derivative form. ${ }^{58}$

In the methodological aspect, the Bint al-Shati' interpretation method namely the critical thematic method, has several advantages: (1) This method allows one to reject the notion of contradictions between the verses of the AlQur'an, as this method ensures no synonymity in the verses of the Al-Qur'an and chronologically arranges the verses studied. (2) The result is more contextual because it departs and aims to solve real problems in society. (3) The Bint al-Shati' method is one of the best ways to understand the Al-Qur'an because it is more precise, comprehensive, and complete.

However, that does not mean there are no criticisms. According to the author, there are several weaknesses in the Bint al-Shati 'interpretation method. First, in the third step, if the understanding of al-Qur'an philosophy must also be studied through the understanding of Arabic which is the main language, even though in fact many terms in Arabic poetry and prose at that time were not used by the Al-Qur'an, then that means opening and leading the entry of foreign elements into the understanding of the Al-Qur'an. This criticism is the same as the criticism noted by Boullata. ${ }^{59}$ Bint al-Shati' himself admits this weakness. In a broader context, this criticism also applies to Izutzu, Rahman, and al-Ghazali's methods.

Second, Bint al-Shati 'appears to be less consistent with the proposed method of interpretation, which examines certain themes but is more of a semantic analysis. When Bint al-Shati' interprets short verses, he collects philosophies that are similar to those that are interpreted and then analyzes them from the perspective of language (semantics). When interpreting the first verse of Surah al-Duhâ, for example, Wa al-Duhâ wa al-Laili izâ Sajâ, she collected all the words duhâ in the Al-Qur'an, but not to find their meaning more thoroughly and comprehensively but rather to analyse the semantic side for support the ideas put forward. This method is no different from the al-Ghazali method above. Therefore, although there is munâsabah al-ayat (comparison of verses), it is not an application of the thematic method proposed.

58 Aishah Abd Rahman Bint al-Shati', Maqâl Fi Al-Insân Dirâsah Qur'aniyah (Cairo: Dar al-Ma'arif, 1969). 101.

${ }^{59}$ Boullata, "Modern Qur'anic Exegesis: A Study of Bint Al-Shati's Method." 


\section{Conclusion.}

Based on the description above, the authors convey the following conclusions. First, the Bint al-Shati 'interpretation method was developed based on the deficiencies in the classical exegesis method. According to Bint al-Shati ', there are two fundamental weaknesses in the classical exegesis method, namely partial interpretation and the inclusion of foreign elements into the interpretation. Bint al-Shati' then formulated a new method of interpretation as a solution, which consists of four steps that combine literary criticism and thematic methods, which the authors call the critical thematic method. This method is peculiar to Bint alShati' although it is adopted from Amin al-Khuli's interpretation principles.

Second, compared to the interpretation method of other contemporary figures, al-Farmawi, Fazlur Rahman, Izutsu, Syahrur, and al-Ghazali, Bint al-Shati' method of interpretation is completer and more detailed. In addition, the Bint alShati' method of exegesis also provides more assurance for the principle that the Koran must speak for itself and that foreign thoughts do not infiltrate the interpretation process.

Third, the method produces several things as a logical consequence. Namely, (1) able to strengthen Abu Abbas Ta'lab's dictum regarding the absence of synonymity in the Al-Qur'an, (2) can be used to break allegations of contradiction between verses of the Al-Qur'an. (3) can provide certainty of the process law in the Al-Qur'an, (4) can strengthen specific theological understanding [.]

\section{Bibliography}

Al-Bab, Ja far Dikk. “Al-Manhaj Al-Lughawi Fi Al-Kitab.” In Al-Kitab Wa AlQur'an Qira'ah Mu asirah, edited by M Shahrur. Damaskus: al-Ahali, 1992.

Al-Farmawi, Abd al-Hayy. Al-Bidayah Fi Tafsir Al-Maudui. Cairo: al-Arabiyah, 1977.

Al-Ghazali, Muhammad. Nahw Tafsîr Maudûi Li Suwar Al-Qur'an Al-Karîm. Cairo: Dar al-Ma'arif, 1996.

Al-Haydari, Kamal. Usul Al-Tafsir Wa Al-Ta'wil. Edited by Abd al-Rida AlIftikhary. Teheran: Satarah, 2012.

Al-Razi, Fakhr al-Din. Al-Tafsîr Al-Kabîr. Beirut: Dar al-Hilal, 1976.

Al-Sațibi, Ibn Musa. Al-Muwafaqat. Edited by Abd Al-Hamid. Cairo: Maktabah M Ali Sabih, 1969.

Al-Zamakhshari, Ibn Umar. Al-Kashshaf'an Haqaiq Al-Tanzil Wa 'Uyun Al-Aqawil Fi Wujub Al-Ta'wil. Beirut: Dar al-Kutub, n.d.

Amin, Muhammad. “A Study of Bint Al-Shati Exegesis.” McGill University, 1992. 
Bint al-Shati', Aishah Abd Rahman. Al-Qur'an Wa Al-Tafsir Al-Asry. Cairo: Dar al-Ma'arif, 1970.

-. Al-Tafsir Al-Bayani Li Al-Qu'an Al-Karim. I. Cairo: Dar al-Ma'arif, 1990.

—. Al-Tafsir Al-Bayani Lil Al-Qur'an Al-Karim. II. Cairo: Dar al-Ma'arif, 1968. . Maqâl Fi Al-Insân Dirâsah Qur'aniyah. Cairo: Dar al-Ma’arif, 1969.

Boullata, Issa J. "Modern Qur'anic Exegesis: A Study of Bint Al-Shati’s Method." The Muslim World LXIV, no. 4 (1974): 103-13. https://doi.org/10.1111/j.1478-1913.1974.tb03145.x.

Denffer, Ahmad Von. Ulul Al-Qur'an: An Introduction to the Scoence of the Qur'an. London: The islamic Foundation, 2009.

Ismail, Maizul Imran \&. “'A 'isha Bint Al-Shāți’s Thoughts On Tarāduf And Their Implications For The Istinbāt Of Law." Al-Risalah 19, no. 2 (2019): 12540. https://doi.org/10.30631/al-risalah.v19i2.459.

Izutsu, Toshihiko. Etika Bergama Dalam Al-Qur'an. Jakarta: Firdaus, 1993.

Jannah, Miftahul. "Manusia Dalam Al-Qur'an (Studi Atas Kitab Maqâl Fî AlInsân: Dirâsah Qur'aniyyah Karya 'Â'Isyah 'Abd Al-Rahman Bint AlSyathi')." Ilmu Ushuluddin 16, no. 2 (2017): 81-94.

Kafrawi, Shalahudin. "Methods Of Interpreting The Qur'ān: A Comparison Of Sayyid Quṭb And Bint Al-Shāți.” Islamic Studies 37, no. 1 (1998): 3-17.

Kumi, Ahmad al-Sayyid and Muhammad Yusuf Qasim. Al-Tafsir Al-Maudu i Li Al-Qur'an Al-Karim. 1st ed. Cairo, 1982.

Mardan. "Tafsir Karya Aisyah Abd Al-Rahman Bint Al-Syathi (Suatu Rekonstruksi Metodologi Tafsir Kontemporer)." Jurnal Adabiyah XI, no. 2 (2011): 166-81.

MD, Jarot Wahyudi. "Literary Interpretation Of The Qur'ān: 'Fawāșil Al-Āyāat, 'Qasam' And "Istifhām, 'Three Examples From Bint Al-Shātțis 'Tafsīr.”' Islamic Studies 37, no. 1 (1998): 19-28.

Mustaqim, Abdul. "Teori Hudûd Muhammad Syahrur Dan Kontribusinya Dalam Penafsiran Alquran." Al-Quds Jurnal Studi Alquran Dan Hadis 1, no. 1 (2017): 1-26. https://doi.org/10.29240/alquds.v1i1.163.

Naguib, Shuruq. "Bint Al-Shati”s Approach to Tafsir: An Egyptian Exegete's Journey from Hermeneutics to Humanity (Review)." Journal of Qur'anic Studies 17, no. 1 (2015): 45-84. https://doi.org/10.3366/jqs.2015.0179. 
Parninsih, Muhammad Alwi; Iin. "Menyoal Konsistensi Metode Penafsiran Bint Syathi Tentang Manusia (Studi Kitab Maqal Fi Al-Insān: Dirasah Qur'aniyyah)." Al-Bayan: Studi Al-Qur" an DanTafsir 4, no. 2 (2019): 8292.

Rahman, Fazlur. Major Themes of the Qur'an. Chicago: Bibliotheca Islamica, 1980.

Ramadhani, Wali. "Bintu Syati' Dan Penafsirannya Terhadap Surah Al-'Asr Dalam Kitab At-Tafsir Al-Bayani Lil Qur'anil Karim.” Jumal At-Tibyan 3, no. 2 (2018): 265-81. https://doi.org/10.32505/tibyan.v3i2.717.

Roded, Ruth. "Bint Al-Shati's Wives of the Prophet: Feminist or Feminine." British Journal of Middle Eastern 33, no. 1 (2006): 51-66. https://doi.org/10.1080/13530190600603915.

Shahrur, Muhammad. Al-Kitab Wa Al-Qur'an Qira'ah Mu'asirah. Damaskus: alAhali, 1992.

Shaltut, Mahmud. Tafsir Al-Qur'an Al-Karim. Cairo: Dar al-Qalam, n.d.

Shihab, Quraish. Membumikan Al-Qur'an. Bandung: Mizan, 1997.

Soleh, Achmad Khudori. Pemikiran Islam Kontemporer. Edited by Achmad Khudori Soleh. Yogyakarta: Jendela, 2003.

Syamsuddin, Sahiron. "An Examination of Bint Al-Shati"s Method of Interpreting the Qur'an.” McGill University, 1998.

Wahyuddin. "Corak Dan Metode Tafsir Bint Al-Shati' Studi Atas Al-Tafsir AlBayaniy Li Al-Qur’an Al-Karim.” Epistemé 9, no. 1 (2014): 117-38. 